\title{
Impact of the gestational week on red cell distribution width in newborns
}

\author{
Yenidoğanlarda gestasyon haftasının eritrosit dağılım genişliği üzerine etkisi
}

Özgül Bulut, Aysimin Akçakaya, Sertaç Arslanoğlu, Fahri Ovalı

Gönderilme tarihi:30.05.2021

Kabul tarihi:23.09.2021

\begin{abstract}
Purpose: Normal data for red cell distribution width (RDW) values in newborns are limited and inconsistent; these values have been interpreted according to adult values in most routine blood counts. The aim of this study is to evaluate the effects of the gestational week on red cell distribution width values in newborns.

Materials and methods: The demographic characteristics and complete blood cell count (CBC) values of the babies admitted to our Neonatal Intensive Care Unit between 2017-2019 were evaluated retrospectively. Newborns were categorized as full-term group (gestational weeks $\geq 37$ ) or preterm group (gestational weeks $<37)$. The mean gestational age, birth weight, sex ratio, hemoglobin $(\mathrm{Hb})$, hematocrit $(\mathrm{Hct})$ and mean corpuscular volume (MCV) values were recorded and RDW values were compared in both groups.

Results: The study population included 485 infants, comprising 250 full-term and 235 preterm babies. The mean gestational age of the full-term group was $38.5 \pm 1.3$ weeks, the mean birth weight was $3198 \pm 478 \mathrm{~g}$, with $7.2 \%$ small for gestational age (SGA) $(n=18)$. The mean gestational age of the preterm group was $32.5 \pm 3.4$ weeks, the mean birth weight was $2015 \pm 815 \mathrm{~g}$, with $5.5 \%$ SGA $(n=13)$. The mean RDW values $(16.1 \pm 1.5)$ in preterm babies were significantly higher than the RDW values $(15.8 \pm 1.3)$ of full-term babies $(p=0.011)$. RDW values of SGA babies were higher in both groups, but there was no significant difference $(p>0.05)$.

Conclusion: Red cell distribution width (RDW), an index of the differential diagnosis of neonatal hematologic diseases, has recently been found to be associated with inflammation. In our study, RDW values were statistically higher in preterm babies than in full-term babies. These findings may be useful in the differential diagnosis and prediction of neonatal diseases, together with other blood count parameters.
\end{abstract}

Key words: Gestational week, newborn, red cell distribution width.

Bulut O, Akcakaya A, Arslanoglu S, Ovali F. Impact of the gestational week on red cell distribution width in newborns. Pam Med J 2022;15:223-227.

\section{Öz}

Amaç: Yenidoğan bebeklerde Eritrosit Dağılım Genişliği (RDW) değerleri ile ilgili normal veriler sınırlı ve tutarsızdır; bu değerler rutin kan sayaçlarının çoğunda yetişkin değerlerine göre kullanılmaktadır. Bu çalışmanın amacı, yenidoğanlarda gestasyon haftasının RDW değeri üzerine etkisini değerlendirmek.

Gereç ve yöntem: Yenidoğan Yoğun Bakım Ünitemizde 2017-2019 yılları arasında yatan bebeklerin demografik özellikleri ve tam kan sayımı değerleri geriye dönük olarak değerlendirildi. Bebekler gestasyon yaşına göre term ( $\geq 37$ hafta) ve preterm (<37 hafta) olarak gruplandırıldı. Her grupta gestasyon haftası, cinsiyet, doğum ağırlığı, hemoglobin, hemotokrit, MCV değerleri kayıt edildi ve RDW değerleri karşılaştırıldı.

Bulgular: Çalışmaya gestasyonel yaşı $\geq 37$ hafta $(n=250)$ ve $<37$ hafta $(n=235)$ olmak üzere 485 bebek alındı. Olguların median gestasyonel yaşı 37 hafta, doğum ağırlığı $2837 \mathrm{gr}$ idi. Preterm bebeklerde ortalama RDW değerleri $(16,1 \pm 1,5)$ term bebeklere göre $(15,8 \pm 1,3)$ anlamlı derecede yüksek saptandı $(p=0,011)$. Her iki grupta da SGA olan bebeklerin RDW değerleri yüksekti, fakat istatistiksel fark saptanmadı $(p>0,05)$.

Sonuç: Eritrosit dağılım genişliği, hematolojik hastalıkların ayırıcı tanısında kullanılan bir indeks olmasının yanında, son çalışmalarda inflamasyonu gösteren bir parametre olarak değerlendirilmeye başlanmıştır. Çalışmamızda preterm bebeklerin RDW değerleri term bebeklerin RDW değerlerine göre daha yüksek saptanmıştır. Bu bulgular yenidoğan hastalıklarının ayırıcı tanısında ve öngörüsünde diğer kan sayımı parametreleri ile birlikte yararlı olabilir.

Anahtar kelimeler: Gestasyon haftası, yenidoğan, eritrosit dağlım genişliği.

Bulut Ö, Akçakaya A, Arslanoğlu S, Ovalı F. Yenidoğanlarda gestasyon haftasının eritrosit dağılım genişliği üzerine etkisi. Pam Tıp Derg 2022;15:223-227.

Özgül Bulut, M.D. Neonatologist, Department of Pediatrics, Division of Neonatology, Istanbul Medeniyet University Goztepe Prof Dr Suleyman Yalcın City Hospital, Kadıkoy/lstanbul, Turkey, e-mail: ozgulbulut@yahoo.com (https://orcid.org/0000-0001-9939-7375) (Corresponding Author) Aysimin Akçakaya, M.D. Department of Pediatrics, Division of Neonatology, Istanbul Medeniyet University Goztepe Prof Dr Suleyman Yalcın City Hospital, Istanbul, Turkey, e-mail: aysiminakcakaya@gmail.com (https://orcid.org/0000-0002-2205-6721)

Sertaç Arslanoğlu, Prof. Department of Pediatrics, Division of Neonatology, Istanbul Medeniyet University Goztepe Prof Dr Suleyman Yalcın City Hospital, Istanbul, Turkey, e-mail: sertacarslanoglu@gmail.com (https://orcid.org/0000-0002-1636-9991)

Fahri Ovalı, Prof. Department of Pediatrics, Division of Neonatology, Istanbul Medeniyet University Goztepe Prof Dr Suleyman Yalcın City Hospital, Istanbul, Turkey, e-mail: fahriovali@gmail.com (https://orcid.org/0000-0002-9717-313X) 


\section{Introduction}

Red cell distribution width (RDW) is a measure of erythrocyte size variation. Traditionally, RDW has been used for the differential diagnosis of anemia [1]. Recently, attention has been drawn toward the prognostic value of RDW in critically ill adults [2-4]. Further, elevated RDW is associated not only with outcome prediction in pediatric critical illness but also provides prognostic information comparable to the more complex Pediatric Index of Mortality (PIM)-2 score. Distinct RDW thresholds help in discriminating between low-risk and highrisk patients in the pediatric population [5]. A previous study has shown some clinical value of RDW measurements to predict disease severity in critically ill neonates [4]. However, reference intervals for hematologic laboratory parameters like RDW in neonates are different from those of the pediatric population. Further, RDW values have been reported to be different in neonates with fetal growth restriction (FGR) or prematurity, but there is insufficient evidence that these parameters directly alter the RDW values [6, 7]. Hence, this study aims to investigate the effects of the gestational week on RDW values in newborns.

\section{Materials and methods}

This retrospective study was performed in newborns admitted to the Neonatal Intensive Care Unit (NICU) between 2017 and 2019. The study was approved by the hospital's ethics committee (2020/0091).

Any infant from birth to three days of age was included in the study. The following data were noted: gestational age, birth weight, sex, hemoglobin $(\mathrm{Hb})$, hematocrit (Hct) and mean corpuscular volume (MCV), RDW values. We excluded those neonates who had congenital diseases, malformations, genetic syndromes. Neonates born to mothers with moderate to severe anemia $(\mathrm{Hb}<8 \mathrm{~g} / \mathrm{dL})$, maternal medications affecting the fetal hemopoietic system, significant antenatal bleeding, and positive family history in terms of hematologic diseases were also excluded. In addition, neonateswith medical conditionssuchashydrops fetalis, intrauterine transfusions, fetomaternal hemorrhage, sepsis, pulmonary hypertension, moderate/severe bronchopulmonary dysplasia and cyanotic congenital heart diseases were excluded. Gestational age was calculated based on the first day of last menstrual period and the Ballard score. Infants with a birth weight less than the 10th percentile were classified as small for gestational age (SGA). Red cell parameters were measured on a fully automated blood cell counter (Mindray BC 6800 Haematology analyzer; Chine).

The study population was divided into 2 groups as per their gestational age. The full term group consisted of patients at 37 weeks and above of gestation, whereas the preterm group was below 37 weeks of gestational age. RDW values were compared in both groups.

\section{Statistical analysis}

Statistical analysis was performed using the NCSS (Number Cruncher Statistical System) 2007 Statistical Software (Utah, USA). Quantitative data were expressed as means \pm standard deviations, and categorical data were expressed as percentages. Pearson's chisquare test and the Student t-test were used to identify differences between the groups. The significance threshold was set to 0.05 .

\section{Results}

A total of 485 neonates (273 male neonates and 212 female neonates) were included in the study. The mean gestational age, birth weight, $\mathrm{Hb}$, Hct, MCV, and RDW of all newborns were $35.6 \pm 3.98$ weeks, $2623 \pm 888 \mathrm{~g}, 17.4 \pm 2.6 \mathrm{~g} /$ $\mathrm{dl}, 51.6 \pm 7.8 \%, 107 \pm 8.95 \mathrm{fL}$, and $15.93 \pm 1.42$ respectively. The baseline characteristics of the neonates based on gestational age are shown in Table 1. Full-term group consisted of 250 neonates and the preterm group consisted of 235 neonates. No differences in the mean $\mathrm{Hb}$ $(\mathrm{g} / \mathrm{dL})$ and hematocrit $(\%)$ values were detected $(p>0.05)$. The mean corpuscular volume (fL) values showed significant differences between the groups $(p<0.01)$. The mean RDW values in the preterm group $(16.1 \pm 1.52)$ were significantly higher than in full- term group (15.8 \pm 1.3$)$ with a $p<0.05$. A total of 31 neonates $(6.4 \%)$ were SGA among the study population, with full-term group comprising a total of 18 SGA neonates, whereas the preterm group comprised a total of 13 SGA neonates. Table 2 depicts the comparison of RDW values among the AGA and SGA neonates in the study population as per the gestational age. The difference in RDW values was higher in the SGA group as compared 
Table 1. Baseline data and outcome of neonates based on gestational age

\begin{tabular}{|c|c|c|c|}
\hline & $\begin{array}{l}\text { Full term infants } \\
\geq 37 \text { wk } \\
(n=250)\end{array}$ & $\begin{array}{l}\text { Preterm infants } \\
<37 \text { wk } \\
(n=235)\end{array}$ & $p$ \\
\hline Gestational age (weeks, mean \pm SD) & $38.54 \pm 1.29$ & $32.46 \pm 3.45$ & $0.0001^{*}$ \\
\hline Birth weight (gram, mean $\pm S D$ ) & $3198 \pm 478$ & $2015 \pm 814$ & $0.0001^{*}$ \\
\hline Male/female (n) & $144 / 106$ & $129 / 106$ & 0.548 \\
\hline SGA (n) & 18 & 13 & 0.453 \\
\hline Hemoglobin $(\mathrm{g} / \mathrm{dL})($ mean $\pm S D)$ & $17.33 \pm 2.64$ & $17.43 \pm 2.58$ & 0.690 \\
\hline Hematocrit (\%) (mean \pm SD) & $51.39 \pm 7.87$ & $51.78 \pm 7.72$ & 0.586 \\
\hline $\mathrm{MCV}(\mathrm{fL})(\operatorname{mean} \pm \mathrm{SD})$ & $105.2 \pm 6.37$ & $108.92 \pm 10.75$ & $0.0001^{*}$ \\
\hline $\mathrm{RDW}(\%)($ mean $\pm \mathrm{SD})$ & $15.77 \pm 1.30$ & $16.0 \pm 1.52$ & $0.011^{*}$ \\
\hline
\end{tabular}

MCV, mean corpuscular volume; RDW, red cell distribution width SGA, small for gestational age; SD, standart deviation. ${ }^{*} p<0.05$

Table 2. Mean RDW values as per SGA/AGA and gestational age

\begin{tabular}{llllll}
\hline & AGA & \multicolumn{5}{c}{ SGA } \\
\hline Gestational Age (week) & Neonates & Mean RDW \pm SD & Neonates & Mean RDW \pm SD & $p$ \\
$\geq 37$ & 232 & $15.77 \pm 1.3$ & 18 & $15.79 \pm 1.28$ & 0.938 \\
$<37$ & 222 & $16.09 \pm 1.5$ & 13 & $16.25 \pm 2.02$ & 0.719 \\
Total & 454 & $15.93 \pm 1.4$ & 31 & $15.98 \pm 1.62$ & 0.826 \\
\hline
\end{tabular}

AGA, appropriate for gestational age; RDW, red cell distribution width SGA, small for gestational age; SD, standart deviation. ${ }^{*} p<0.05$

with the AGA group but the difference was not statistically significant in both groups $(p>0.05)$.

\section{Discussion}

Reference intervals of laboratory values during the neonatal period are different from those of adults and children and they change considerably with the prenatal condition, in particular, prematurity is a significant variable. Thus, specific ranges are important for neonatal monitoring and diagnosis, on the other hand, it is difficult to obtain samples from neonates because of ethical implications and for the paucity of available biological samples. Measures of RDW do not require extra samples and this parameter is routinely given with $\mathrm{CBC}$ since $\mathrm{CBC}$ itself is frequently required for clinical management.

In newborns, the normal values of RDW have been previously found higher than those of other children groups, but the normal values in preterm infants are lacking with few reports $[8,9]$. In the present study, our results indicated that RDW values are different among gestational ages and gestational age affects the RDW values. The mean values of RDW were significantly higher in the preterm group than in the full-term group. Studies are supporting these findings, Desai et al. [10] showed that the RDW values of the preterm infants were higher significantly than their term counterparts. Christensen et al. [7] confirmed that the gestational period affects RDW. RDW\% mean (SD) values ranged from $17.86(2.23)$ at 3234 weeks of gestational age to $16.65(1.81)$ at 37-42 weeks. Tonbul et al. [9] indicate that the normal range for RDW values at 32-34 weeks is higher than those at 35-36 gestational weeks and at 37-42 weeks of gestational age. RDW of all the neonates resulted however to be higher than RDW of children and adults comparing our results with literature [11]. From all these results, we think that unstable erythropoiesis and stress condition is reflected in the higher RDW values in preterm infants.

Desai et al. [10] reported that the RDW values of SGA neonates were found to be higher than their AGA neonates. The authors explained this by the fact that chronic fetal hypoxia caused by poor placental function leads to increased erythropoiesis in the SGA neonates. In our study, the RDW values of SGA neonates were higher than their AGA neonates in both groups, but the difference was not statistically significant. This 
can be attributed to the small sample size in SGA infants.

In addition, RDW has been mainly used in the differential diagnosis of anemia but has been recently demonstrated to have a role in adult patients as a prognostic marker in different pathologies, mainly for cardiovascular diseases [11, 12]. In recent years, studies evaluating the relationship between RDW and morbidities and mortality in newbrons have been performed [1316]. A recent study has shown that patients with persistent pulmonary hypertension (PPHT) had a significant increase in RDW and that RDW could be an independent predictor of PPHT [14]. It has also been shown in a recent study that the elevated RDW value is associated with bronchopulmonary dysplasia in the preterm infants [15]. In our study, cases with sepsis, pulmonary hypertension, and moderate-tosevere bronchopulmonary dysplasia were not included in the study, so the relationship between RDW and these diseases was not evaluated. The results of our study may help for such studies on the diseases of newborns.

The present study has a few limitations. First, maternal iron status, which can affect the iron status of neonates, was not assessed. However, this factor is less likely to affect the study outcome, as the neonates born to moderately or severely anemic $(\mathrm{Hb}<8 \mathrm{~g})$ mothers were excluded. This is in line with previous studies which showed that the iron status of pregnant women with mild anemia seemed to have no significant impact on the iron status of their neonates [17]. Another limitation was that the reticulocyte count was not calculated separately. Neonates are known to have physiological reticulocytosis, which could influence the RDW. However, in the present study, we studied all neonates in the early postnatal period, which is characterized by a high reticulocyte count.

In conclusion, during the newborn period, the normal range of RDW differs among newborns in terms of gestational age. Additionally, our results suggest that RDW values should be evaluated according to these specific results for diagnosis of newborn disease without respect to adult or child values. Because RDW in neonates is elevated as compared with that in adults and reflects significant variability in the size of the RBCs. If these are taken into consideration, our study could be useful as a baseline of RDW values in newborns. Future prospective studies with more newborns are needed on this issue.

Conflict of interest: The authors declare no conflicts of interest.

\section{References}

1. Qurtom HA, Al Saleh QA, Lubani MM, et al. The value of red cell distribution width in the diagnosis of anaemia in children. Eur J Pediatr 1989;148:745-748. https:// doi.org/10.1007/BF00443100

2. Ku NS, Kim HW, Oh HJ, et al. Red blood cell distribution width is an independent predictor of mortality in patients with gram-negative bacteremia. Shock 2012;38:123127. https://doi.org/10.1097/SHK.0b013e31825e2a85

3. Felker GM, Allen LA, Pocock SJ, et al. CHARM Investigators. Red cell distribution width as a novel prognostic marker in heart failure: data from the CHARM Program and the Duke Databank. J Am Coll Cardiol 2007;50:40-47. https://doi.org/10.1016/j. jacc.2007.02.067

4. Meynaar IA, Knook AHM, Coolen S, et al. Red cell distribution width as predictor for mortality in critically ill patients. Neth J Med 2013;71:488-493.

5. Ramby AL, Goodman DM, Wald EL, Weiss SL. Red blood cell distribution width as a pragmatic marker for outcome in pediatric critical illness. PLoS One 2015;10:e0129258. https://doi.org/10.1371/journal. pone.0129258

6. Garofoli F, Ciardelli L, Mazzucchelli I, et al. The red cell distribution width (RDW): value and role in preterm, IUGR (intrauterine growth restricted), full-term infants. Hematology 2014;19:365-369. https://doi.org/10.1179/ 1607845413Y.0000000141

7. Christensen RD, Yaish HM, Henry E, Bennett ST. Red blood cell distribution width: reference intervals for neonates. J Matern Fetal Neonatal Med 2015;28:883888. https://doi.org/10.3109/14767058.2014.938044

8. Ozyürek E, Cetintaş $\mathrm{S}$, Ceylan $\mathrm{T}$, et al. Complete blood count parameters for healthy, small-for-gestational-age, full-term newborns. Clin Lab Haematol 2006;28:97104. https://doi.org/10.1111/j.1365-2257.2006.00767.x

9. Tonbul A, Tayman C, Catal F, Kara S, Tatli MM. Red cell distribution width (RDW) in the newborn: normative data. J Clin Lab Anal 2011;25:422-425. https://doi. org/10.1002/jcla.20496

10. Desai SA, Martin SL, Nanavati RN, et al. Red cell distribution width (RDW): normative data in Indian neonates. J Pediatr Hematol Oncol 2019;41:119-121. https://doi.org/10.1097/MPH.0000000000001164

11. Montagnana M, Cervellin G, Meschi T, Lippi G. The role of red blood cell distribution width in cardiovascular and thrombotic disorders. Clin Chem Lab Med 2011;50:635641. https://doi.org/10.1515/cclm.2011.831 
12. Hong $\mathrm{N}$, Oh J, Kang SM, et al. Red blood cell distribution width predicts early mortality in patients with acute dyspnea. Clin Chim Acta 2012;413:992-997. https://doi.org/10.1016/j.cca.2012.02.024

13. Ellahony DM, El Mekkawy MS, Farag MM. A Study of red cell distribution width in neonatal sepsis. Pediatr Emerg Care 2020;36:378-383. https://doi.org/10.1097/ PEC. 0000000000001319

14. Sagheb S, Sepidarkish M, Mohseni SO, Movahedian A, Mosayebi Z. Red cell distribution width as a predictor of persistent pulmonary hypertension of the newborn. Am J Perinatol 2017;34:1442-1446. https:// doi.org/10.1055/s-0037-1604246

15. Dogan P. The role of red cell distribution width as a predictor of bronchopulmonary dysplasia in preterm Infants. Haydarpasa Numune Med J 2020;60:41-45. https://doi.org/10.14744/hnhj.2019.53824

16. Martin SL, Desai S, Nanavati R, Colah RB, Ghosh $\mathrm{K}$, Mukherjee MB. Red cell distribution width and its association with mortality in neonatal sepsis. J Matern Fetal Neonatal Med 2019;32:1925-1930.https://doi. org/10.1080/14767058.2017.1421932

17. Paiva AdeA, Rondó PHC, Pagliusi RA, Latorre MdoRDO, Cardoso MAA, Gondim SSR. Relationship between the iron status of pregnant women and their newborns. Rev Saude Publica 2007;41:321-327. https://doi.org/10.1590/s0034-89102007000300001

Ethics committee approval: Istanbul Medeniyet University Goztepe Training and Research Hospital, Ethics Committee (approval date: 05.02.2020 and number: 2020/0091).

\section{Authorship contributions}

Study Design: Ö.B.;

Data Collection: Ö.B., A.A.;

Analysis: Ö.B., A.A.;

Writing: Ö.B.;

Approval: S. A., F.O. 